\title{
The influence of internal and external rewards on people's behavior regarding tax evasion practices in Brazil
}

\author{
Ivone Vieira Pereira ${ }^{1}$ \\ (D) https://orcid.org/0000-0001-9234-5708 \\ Email: ivonevp@brturbo.com.br
}

\author{
César Augusto Tibúrcio Silva² \\ (D) https://orcid.org/0000-0002-5717-9502
}

Email: cesartiburcio@unb.br

\author{
1 Universidade de Rio Verde, Departamento de Ciências Contábeis, Rio Verde, GO, Brazil \\ 2 Universidade de Brasília, Faculdade de Economia, Administração, Contabilidade, Economia e Gestão de Políticas Públicas, Departamento de \\ Ciências Contábeis e Atuariais, Brasília, DF, Brazil
}

Received on 06.20.2018 - Desk acceptance on 07.10.2018 - $5^{\text {th }}$ version approved on 10.10.2019 - Ahead of print on 03.02.2020

Associate Editor: Eliseu Martins

\begin{abstract}
This research aimed to identify the factors that influence people's behavior with regard to tax evasion practices in Brazil based on an analysis of the internal and external rewards. The study analyzes internal and external rewards as a determining factor of tax evasion, unlike other studies that have focused on analyzing economic and social factors. The topic is addressed from a contemporary perspective, based on a behavioral analysis of economic and social factors. The paper contributes with its conceptual refinement and assumptions that may strengthen the foundations for studying the factors that influence tax evasion. The data collection was carried out by means of a quasi-experiment followed by the application of a questionnaire, in the period from November of 2016 to September of 2017, in loco, with 800 data collection instruments in all the geographic regions of the country, 598 of which were validated. Measures were adopted to ensure the content, criteria, and construct validities. The reliability test resulted in a Cronbach's alpha of 0.63 and the composite reliability was higher than 0.60 . The data were analyzed based on descriptive statistics and using the binary logistic regression model. The results of this research illustrate, by means of the logistic regression analysis using a univariate approach, that external rewards - punishment - and internal rewards - self-concept, social norms, fiscal transparency, and cost of compliance - influence people's dishonest behavior with regards to tax evasion practices in the sample studied. The study analyzes tax evasion based on an interdisciplinary approach, cooperating with the public administration in determining actions that can discourage evasion, by implementing strategies that include behavioral factors relating to the taxpayer.
\end{abstract}

Keywords: rewards, dishonesty, behavior, tax evasion. 


\section{INTRODUCTION}

Using data collected for a global investigation on sociocultural and political values, the World Values Survey (2015) indicated that, in Brazil, there is a tendency to not pay taxes, which is consistent with the estimate presented by the National Union of National Treasury Agents (Sinprofaz), which indicated R $\$ 500$ billion in evaded taxes in Brazil in 2016 (Pernías, 2017).

The empirical evidence used to investigate tax evasion has increased since the first analysis carried out by Allingham and Sandmo (1972), who structured a theoretical decision-making model with the aim of explaining what causes a taxpayer to evade taxes. Tax evasion is considered a dishonest act relating to non-compliance with a norm, as explained by Becker (1968). Thus, Attribution Theory, as suggested by social psychology, assumes that human behavior is motivated by internal and external factors, since individuals explain the causes of and reasons for their behavior (Heider, 1958). Internal factors represent the attitudes exercised through the individual's willingness and control and external factors are attitudes stimulated by someone or by a particular situation.

Along these lines, Mazar and Ariely (2006) argue that external rewards elucidate our understanding of human behavior from an economic approach, while internal rewards reflect the internalization of social norms, which vary endogenously with the environment in which the individual is located.

In Brazil, the research that investigates taxpayer behavior with regard to tax evasion is limited. Siqueira and Ramos (2006) explained how the taxpayer's behavior influences the level of evasion. In the international realm, various empirical observations have been made since the 1960s, with an emphasis on influences of a social and cultural nature (Thibaut, Friedland \& Walker, 1974), as well as psychological one (Adams, 1965), in particular, for this study, regarding tax questions (Alm, 2012; Andrighetto et al., 2016; Baldry, 1986; Bloomquist, 2006; Mittone, 2006; Spicer \& Lee Becker, 1980; Zaklan, Westerhott \& Stauffer, 2009).

Studies related to factors that influence tax evasion practices, such as those by Mittone (2006), Torgler and
Schneider (2007), Alm (2012), Sá, Martins, and Gomes (2014), Pickhardt and Prinz (2014), and Andrighetto et al. (2016), have been carried out in developed countries - the United States of America and countries in Europe - whose cultural and economic aspects differ from the Brazilian environment due to the fact that they have efficient institutions, a transparent tax system, clear auditing rules, developed economies, and they present consistent tax compliance.

In light of the above, this study aims to answer the following research question: which factors influence people's behavior with regard to tax evasion practices in Brazil? Hence, the aim of this research is to identify the factors that influence people's behavior in terms of practicing tax evasion in Brazil based on an analysis of the internal and external rewards.

This study addresses the topic by investigating human behavior that can influence tax evasion. This enables a comparison with the findings of studies from other countries and the confirmation of findings from previous research, since the study analyzes internal and external rewards as a determining factor of tax evasion, unlike other studies that have focused on analyzing economic and social factors.

The contributions of this study are applicable to the theoretical and practical fields. From a practical viewpoint, the research contributes to public management by defining effective strategies for inhibiting illicit practices, in terms of presenting evidence that can enable the implementation of tax actions based on economic, social, and behavioral factors. Moreover, for Birnberg, Turopolec, and Young (1983), these illegal acts can distort information systems. Considering the theoretical contributions, the study analyzes elements derived from the Expected Utility Theory (EUT) and Attribution Theory to determine the priority relationship and probabilities associated with tax evasion.

Including this introduction, this paper is structured in five sections. Section 2 covers the literature review, section 3 reports on the methods applied, and section 4 addresses and discusses the results obtained in the research. Finally, section 5 deals with the main findings and provides the concluding remarks. 


\section{THEORETICAL FRAMEWORK}

\subsection{Behavioral Aspects}

The decision-making process can be considered a fundamental cognitive function for an individual's effective interaction with their social environment (Schneider \& Parente, 2006).

Rachlin (1970) argues that the control exercised by an individual over their behavior is related to self-control. The author states that an individual gets involved in some behavior rather than another by taking into consideration immediatism versus the punishment. Along these lines, Thaler and Shefrin (1981) state that the influence of a false consensus is present in cooperative decisions regarding a problem, and the loss of self-control is combatted by the imposition of rules. Moreover, Thaler (1990) says that people perceive self-control to be difficult and, thus, make decisions to restrict their future behavior.

Therefore, the Attribution of Causality Theory emerges from the context in which individuals not only observe the facts that occur around them, but also seek causes and effects to explain those facts (Heider, 1958). From this perspective, Weiner (1976) suggests explaining the attributions of causes related to internal and external factors.

Mazar, Amir, and Ariely (2008) refer to the external cost-benefit perspective as being when individuals act honestly or dishonestly, based on actions that aim to maximize their own interests. However, for the authors, from a psychological viewpoint, and going beyond financial considerations, decisions involving dishonesty are influenced by the internal rewards. Bem (1972) and Baumeister (1998) state that the internal reward, in the context of dishonesty, influences the way people see themselves in relation to each situation, since every individual considers themselves to be honest and that that honesty has a positive moral value. Thus, researchers argue that individuals internalize the norms and values of society, using them as an internal reference to evaluate their own behavior (Campbell, 1964; Dilulio \& John, 1996; Henrich, et al., 2001; Mazar \& Ariely, 2006).

\subsection{Tax Evasion and the EUT Model}

Falcão (2002) used the expression tax evasion to describe the abuse of legal forms. In practice, in cases of tax evasion practices there is atypicity in the legal form adopted in relation to the aim, to the practical intention pursued, in order to achieve tax evasion. Hanlon and
Heitzman (2010) define evasion as being actions that aim to reduce taxes, independently of the legality.

The explanatory theoretical model of taxpayer behavior proposed by Allingham and Sandmo (1972) adopts the expected utility structure to analyze decisions to practice tax evasion. Becker (1968) observed that an individual's decision to practice tax evasion is made in a situation of uncertainty, because there is uncertainty regarding the punishment for the illicit practice.

The EUT is assumed as a rational expected utility maximizer, with risk aversion (Von Neumann \& Morgensten, 1953). Thus, utility is a function of income $(I)$, where the tax rate is a constant $(t)$ over declared income $(X)$ and the taxpayer assumes that the tax authority attributes a probability $(p)$ to investigating tax evasion and a penalty rate for undeclared income $(I-X)$, which is greater than $t$.

In turn, the taxpayer assumes the risk of undervaluing their real income when the penalty is lower than the result of the penalty rate applied on undeclared income. Thus, for there to be tax compliance, the detection probability and penalties should be adjusted according to increases in the tax rate.

In support of the EUT perspective, Friedland, Maital, and Rutenberg (1978) state that individuals with risk aversion avoid tax evasion when the penalty rate and the detection probability are increased. Thus, the tax evasion model proposed by Allingham and Sandmo (1972) indicates that, under the risk aversion hypothesis, such evasion increases as income increases, because riskaverse individuals are willing to assume more risk if their level of wealth increases. However, the model does not explore at what level of increase in income risk aversion influences tax evasion.

Having said that, experimental studies have indicated that individuals do not behave according to the rules of the EUT (Karni \& Safra, 1987; Loomes, Starmer \& Sugden, 1991), revealing that there is the possibility of preference inversion. Thus, the essence of the Prospect Theory, presented by Tversky and Kahneman (1992), assures that human behavior is influenced by their reaction to gains and losses, and not by the expected result of their choices, given that individuals with aversion to losses codify them as being more painful than similar-sized gains.

Preference inversion occurs due to a change in how a situation is presented, given the sensitivity of cognitive 
biases, as well as the inherent characteristics of individuals that enable them to control their actions. For Rachlin (1970), self-control involves a choice situation in which the response alternatives differ with regard to the delay and magnitude of the reinforcing stimulus. Another important point involves the consumption time, since intertemporal demand explains that an individual can optimize their utility by making a choice between consuming now or consuming in the future. From this perspective, Dean, Keenan, and Kenney (1980) criticized the EUT of Allingham and Sandmo (1972), arguing that the analysis assumptions of the tax evasion model do not take into consideration the individual's behavior, where social norms, feelings of justice, the cost of tax compliance, and the interaction between the taxpayer and the tax authority are determining factors for tax evasion.

In light of the above, it is observed that expected utility maximization is equivalent to the hypothesis that choice behavior satisfies some restrictions on the form of unquestionable truths; thus, it is possible to establish an expected utility function that represents an individual's preferences. However, the economic determinants alone, based on the detection probability, on the penalty, the income, and the tax rate, are not enough to explain the attitude of taxpayers with regard to meeting their tax obligations, given the fact that the models ignore individuals' intrinsic motivations.

\subsection{External Rewards}

External factors refer to actions stimulated or incited by someone or by a particular situation. Weiner (1976) notes that the cultural influence dimension related to motivation and judgement of performance can have an impact on the way the perception of causality occurs. For Mazar and Ariely (2006), the hypotheses that can guide the magnitude of the reward are: a lower probability of being detected and a lower penalty.

Thus, it is assumed that the relationship between expected benefits and dishonesty and the propensity for dishonesty is linear.

The probability of the benefit being detected is operationalized by means of inspection, which implies penalties applied through fines. Fines are used to control activities that impose external costs - that is, costs that are imposed on third-parties - aiming to prevent individuals from getting involved in them. Yet, individuals get involved in these activities when the private benefits are greater than the external costs (Allingham \& Sandmo, 1972; Becker, 1968).

Polinsky and Shavell (1979) and Polinsky (2004) state that individuals get involved in activities that generate external costs, independently of the probability of them being detected, and suggest that the value of the penalty should not be increased according to the probability of detecting them, given the individual's financial inability to pay the fine, but instead according to the external costs generated.

For Alm (1995), punitive actions affect compliance with a rule up to a certain point and the penalty does not explain the whole illicit practice, since compliance with a rule is a complex action and can be influenced by rewards given to the individual.

Butterfield, Trevino, and Ball (1996) state that penalties can generate extenuating circumstances associated with unsuitable behavior and that they should involve, in their applicability, a consistent, appropriate, and fair result. From this perspective, the findings of Trevino (1992) showed that organizational members are sensitive to justice given that, when faced with a penalty, they care about knowing whether the disciplinary procedures are aligned with the values and fundamental rules of the group and whether they are applied with neutrality.

In the context of the tax system, to understand the penalty and detection probability, revenue is considered an important component, made up of three parameters: the tax rate, the audit frequency, which can be defined as the fraction of total tax statements audited, and the magnitude of the fine (Friedland et al., 1978). The interpretation is that when income is not taxed, the entire income is declared; however, when there is an absence of declared income, the liability on the declared income declines with an increase in the rate and with a reduction in the levels of auditing.

\subsection{Internal Rewards}

Internal factors are the attitudes executed through the individual's free will and control. Thaler and Shefrin (1981) consider that self-control concerns an agency conflict between the rational part and the emotional part of an individual that can contribute to the loss of self-control.

Studies demonstrate that, as part of socialization, individuals internalize the norms and values of society, forming beliefs that guide their behavior (Dilulio \& John, 1996; Henrich et al., 2001). Rokeach (1973) characterizes values as something that goes beyond specific realities, while attitudes are related to a particular reality. Thus, an individual who has internalized positive values has a belief that guides their attitudinal and behavioral standards, comparing others and themselves, and this determines their form of conduct. Therefore, socialization is a process through which an individual's actions depend on 
impersonal causality because they are subject to external forces, to the environment (Heider, 1958).

In studies on social norms concerning taxation, Schwartz and Orleans (1967) believe that appeals to conscience are more effective than penalties because punishments produce resistance to compliance, inducing a moralistic attitude in relation to compliance with a rule; so, this resistance can be minimized by alternative techniques for ensuring compliance, such as the use of appeals to conscience or a sense of civic responsibility.

This research limits itself to studying the religiosity, self-concept, social norms, cost of tax compliance, and fiscal transparency variables, which are addressed below.

Religiosity is defined by McDaniel and Burnett (1990) as a belief in God accompanied by a commitment to follow the principles that are believed to be established by Him and that provide a community of faith, with teachings and narratives that incentivize morality.

For Glover (1997), an individual's moral reasoning is partly subject to the importance given to their religious beliefs. Allport (1950) suggested that religion assumes different roles in an individual's life and maintains that the intrinsic nature of religion represents an internal guarantee for daily life, while the extrinsic nature represents the outside role of religion for society or even for individual contentment.

Seeking to identify the moderating variable of religiosity in the relationship between ethics and tax evasion, Lau, Choe, and Tan (2013) revealed that there is a positive relationship between ethics and tax evasion, where the emphasis given to the importance of money incentivizes tax evasion practices.

With regard to self-concept, Aronson (1969) and Bem (1972) state that the best way for an internal reward to exercise control over individuals' behavior would be to influence their self-concept. This occurs because personal norms guide an individual's decisions based on their beliefs; thus, the individual updates their self-concept based on their personal references. Therefore, self-concept is understood as the way individuals see and perceive themselves. For Thaler and Shefrin (1981), the loss of self-control can be combatted by the imposition of rules.

In this context, to maintain a positive self-concept, individuals respect their internal standards even if they have to make a financial sacrifice (Harris, Mussen \& Rutherfod, 1976). However, Thaler (1999) states that mental accounting influences individuals' choices because the rules modify the objectives.

Consequently, Mazar and Ariely (2006) reveal that the level of dishonesty in itself can activate internal reward mechanisms, ending the linear relationship between the external rewards and the propensity for honesty. In this case, the benefits of the external rewards are likely to exceed the benefits of the internal rewards of maintaining a positive self-concept.

Research reveals that when an individual encounters the possibility of practicing an illicit act, they will do so; however, they will maintain a balance between the incentive of profiting and their positive attitude toward themselves. In this case, the individual understands that the practiced act is not dishonest and sees it as an acceptable limit according to their internal norms (Fischbacher \& Föllmi-Heusi, 2013; Fosgaard, 2013; Ploner \& Regner, 2013; Shalvi \& Leiser, 2013).

Given this context, it is perceived that the way people feel with regard to dishonest acts in which they can update their self-concept, either positively or negatively, according to their actions, influences honest behavior. However, when individuals are not attentive to their own moral standards, their actions will not be evaluated in relation to the norms themselves; therefore, their behavior can diverge from their standards, because their self-concept is more likely not to be updated.

Cialdini and Trost (1998) define social norms as rules and standards understood by the members of a group, which restrict social behavior. For Durkheim (1949), social norms regulate the place and the role of individuals in social life, ensuring the functioning and cohesion of society. In this sense, Wenzel (2004) states that personal norms indicate an individual's moral standards and behavioral expectations, that is, the norms on which their own personal standards are based, and are a product of socialization, are influenced by the social norms of the group to which they belong.

Heider (1958) had already proposed that actions are derived from personal or impersonal causality, where personal causality depends on the individual's internal control and impersonal causality is subject to the external forces of the environment. Another factor that influences the decision to evade taxes are the costs of the resources needed to comply with the tax rules, called "costs of tax compliance," or psychological costs, as identified in the history of economics by Adam Smith (1776) and taken as a definition of compliance costs by Sandford, Godwin, and Hardwick (1989).

Evans, Lignier, and Tran-Nam (2013) state that compliance costs can determine the magnitude of tax compliance. Thus, Shaw, Slemrod, and Whiting (2008) showed that compliance costs tend to be lower when the tax system is less complex.

Considering that the tax system should be transparent to prevent tax evasion, it is believed that complexity 
of the rules enables such evasion (Chiarini, Marzano \& Schneider, 2013). Thus, the magnitude of the legal complexity has a positive relationship with tax evasion because difficulties in simplifying the bureaucracy of the tax system contribute to tax collection problems, as well as generating costs for the taxpayer to be in compliance with the tax requirements, including knowledge of the tax rules, programs, and fulfillment of obligations (Diniz, Barbosa, Junqueira, \& Prado, 2009).

Thus, Chau and Leung (2009) state that growth in complexity of the legislation, through excessive details with regard to starting companies, the tax rules, or in the informational requirements and auditing costs, is positively associated with an increase in tax evasion. However, an increase in the complexity of the legislation can make separating honest taxpayers from dishonest ones difficult because non-compliance with tax obligations can be unintentional on the part of the taxpayer, as they were unable to correctly interpret the legislation.

The interaction between the taxpayer and the tax authority evaluated based on fiscal transparency is another variable that can influence tax evasion practices. For Mota (2012), transparency is the attribute of being transparent, clear, and visible. In this sense, transparency is defined as making data available to the general public on the structure, roles of the government, fiscal intentions, and public sector accounts, with the aim of enabling society to accurately evaluate the government's financial position and the costs and benefits of the activities it carries out (Kopits \& Craing, 1998).

\section{METHODOLOGY}

Regarding the technical approach, a quasiexperimental procedure and questionnaires were used. A quasi-experiment was chosen, given the adaptation of the original experiment, as well as the absence of randomness of the treatments. The questionnaire was constructed from an ordered and consistent set of questions regarding the constructs that we intended to measure.

\subsection{Expected Participant Profile and Sample}

The expected profile for the participants in this study was private individuals, living in Brazil, who presented an Annual Income Tax Return for Private Individuals (Declaração de Ajuste Anual do Imposto de Renda Pessoa Física - DAA-IRPF) relating to the 2016 tax year.

The sample was built according to accessibility to post-graduation programs, events promoted by the
Ellis and Fender (2003) analyzed the corruption and transparency variables with an emphasis on the government's behavior and found that the higher a country's level of fiscal transparency, the lower the percentage of corruption. Corroborating with these results, Zuccolotto and Teixeira (2014) carried out a study in Brazilian states to discover the causes of fiscal transparency. The authors found that these causes are associated with better socioeconomic and human development, with a high level of competition, and with a low level of corruption.

In this sense, Torgler (2003), Kogler et al. (2013), and Pickhardt and Prinz (2014) explain that trust in the authorities is positively reflected in a reduction in tax evasion. Feld and Frey (2007) showed that mutual respect between taxpayers and tax authorities increases the level of compliance with tax obligations.

Also regarding fiscal transparency, Andrighetto et al. (2016) carried out an experiment with Italians and Swedes, individuals from countries in which the tax system is transparent and the sanctions and auditing rules are clear, and they found that the average level of honesty is relatively high in both countries, and the average levels of tax evasion did not differ significantly. What could be observed were merely different types of dishonesty between the countries.

In light of the above, the behavior of individuals with regard to tax evasion practices is expected to be negatively related with the internal and external rewards.

Regional Accounting Councils (Conselhos Regionais de Contabilidade - CRCs), and representative trade associations, for groups formed of up to 25 research subjects. After receiving authorization from the party responsible, we proceeded to apply the data collection instrument on site on the date and at the time set. Therefore, the sampling was classified as non-probabilistic and convenience, given that the data were not obtained randomly.

The sample was distributed by region as according to Table 1. Despite the sample distribution not representing the Brazilian population distribution by geographic region at the time of conducting the research, the analysis of variance was used to verify the statistical differences between the regions for the internal and external rewards variables and they are shown in Table 1. 
Table 1

Sample distribution by region

\begin{tabular}{|c|c|c|c|c|}
\hline Regions & Relative frequency $(\%)$ & Absolute frequency (n) & F test & p-value \\
\hline Central-West & 29.40 & 176 & 1.117 & 0.160 \\
\hline Northeast & 17.60 & 105 & 3.535 & 0.037 \\
\hline North & 23.90 & 143 & 2.579 & 0.085 \\
\hline Southeast & 11.40 & 68 & 0.156 & 0.955 \\
\hline South & 17.70 & 106 & 2.226 & 0.140 \\
\hline Total & 100.00 & 598 & & \\
\hline
\end{tabular}

Source: Elaborated by the authors.

Using the $1 \%$ significance level ( $\mathrm{p}$-value $<0.01$ ), the regions did not present statistical differences. But at $5 \%$, the results for the Northeast region were significant. And despite using convenience sampling, the sample size was greater than the statistically minimum size, which would be 384 individuals defined for the $95 \%$ confidence level and $5 \%$ margin of error.

\subsection{Material and Procedure}

The model used in this research was based on the experiments of Mazar and Ariely (2006) and Mazar et al. (2008). The authors developed a mathematical test in which the research participants were paid for performance. The test sheet was composed of 20 tables, each one with a group of 12 three-digit numbers, and the participants had five minutes to find two digits per table that added up to 10 , and they were remunerated for their performance.

For this study, one modification carried out in the original experiment involved paying for each participant's performance, where on the act of payment the participants were told that this would be fictitious, in compliance with all the mandatory submission terms established in Resolution n. 466/2012 of the National Health Council.

To obtain greater precision regarding the participants' honesty, the experiment was adapted so that, in the control groups, the tests were preserved and not disposed of in a shredder, as according to the original experiment; the participants were asked to dispose of the tests in a trash can. On the act of payment, they only had the collection voucher and socioeconomic questionnaire in their hands. There was an identification on the collection vouchers and on the mathematical test sheets, corresponding to each one, with the aim of verifying the participants' real performance.

Table 2 summarizes the motivations for honesty suggested for reducing illicit practices presented by Mazar and Ariely (2006), the independent variables that led to the elaboration of the data collection instrument, as well as the questions that formed part of the data collection instrument.

Table 2

Aim of the questions of the data collection instrument

\begin{tabular}{|c|c|c|c|}
\hline Attribution & Element & Interpretation & Authors \\
\hline \multicolumn{4}{|c|}{$\begin{array}{c}\text { Question } 5 \text { - Suppose that you had an income of } R \$ 10,000.00 \text { and should pay } R \$ 1,500.00 \text { in taxes. But if you reduce your earnings } \\
\text { to } R \$ 9,000.00 \text {, you will have no tax to pay; however, if the Internal Revenue Service catches you, you will pay a fine } \\
\text { of } R \$ 1,000.00 \text {. Would you run the risk of declaring the lower amount? }\end{array}$} \\
\hline \multirow{2}{*}{$\begin{array}{l}\text { External } \\
\text { reward }\end{array}$} & Magnitude of the reward & $\begin{array}{l}\text { The participants with a propensity for dishonesty are } \\
\text { expected to answer "yes" or "don't know." }\end{array}$ & $\begin{array}{l}\text { Heider (1958), Allingham and } \\
\text { Sandmo (1972), Mazar and Ariely } \\
\text { (2006) }\end{array}$ \\
\hline & Penalty & $\begin{array}{l}\text { The participants with a lower propensity for dishonesty } \\
\text { are expected to answer "no." }\end{array}$ & $\begin{array}{l}\text { Nagin and Pogarsky (2003), } \\
\text { Castillo, Petrie, Torero, and } \\
\text { Viceisza (2011) }\end{array}$ \\
\hline \multicolumn{4}{|c|}{ Question 5.1 - And if the fine was $R \$ 2,000.00$, would you run the risk? } \\
\hline \multirow{2}{*}{$\begin{array}{l}\text { External } \\
\text { reward }\end{array}$} & Magnitude of the reward & $\begin{array}{l}\text { The participants with a propensity for dishonesty are } \\
\text { expected to answer "yes" or "don't know." }\end{array}$ & $\begin{array}{l}\text { Heider (1958), Allingham and } \\
\text { Sandmo (1972), Mazar and Ariely } \\
\text { (2006) }\end{array}$ \\
\hline & Penalty & $\begin{array}{l}\text { The participants with a lower propensity for dishonesty } \\
\text { are expected to answer "no." }\end{array}$ & Becker (1968) \\
\hline
\end{tabular}


Table 2

Cont.

\begin{tabular}{|c|c|c|c|}
\hline Attribution & Element & Interpretation & Authors \\
\hline \multicolumn{4}{|c|}{$\begin{array}{l}\text { Question } 6 \text { - Without counting weddings, funerals, and christenings, how often do you currently go to church? } \\
\text { More than once a week, once a week, once a month, only on religious days, once a year, or never? }\end{array}$} \\
\hline $\begin{array}{l}\text { Internal } \\
\text { reward }\end{array}$ & The individual's religiosity & $\begin{array}{l}\text { In which "never" are the individuals with a higher } \\
\text { propensity for tax evasion and "sometimes" and "often" } \\
\text { are those with a lower propensity for tax evasion. }\end{array}$ & $\begin{array}{l}\text { Lau et al. (2013), Shalvi and } \\
\text { Leiser (2013), and Sá, Martins, } \\
\text { and Gomes (2014) }\end{array}$ \\
\hline \multicolumn{4}{|c|}{$\begin{array}{c}\text { Question } 7 \text { - "Evasion is a crime." Suppose you had an income of } R \$ 100,000.00 \text { and should pay } R \$ 15,000.00 \text { in taxes. But if you reduced } \\
\text { your earnings to } R \$ 80,000.00 \text {, you should pay } R \$ 10,000.00 \text {. Would you run the risk of declaring the lower amount? }\end{array}$} \\
\hline $\begin{array}{l}\text { Internal } \\
\text { reward }\end{array}$ & Self-concept & $\begin{array}{l}\text { Based on the expression "evasion is a crime," } \\
\text { individuals who answered "yes" or "don't know" are } \\
\text { expected to be influenced into practicing tax evasion. } \\
\text { Those who answered "no" are considered less dishonest. }\end{array}$ & $\begin{array}{l}\text { Heider (1958), Bem (1972), } \\
\text { Thaler and Shefrin (1981), Torgler } \\
\text { (2007), Mazar, Amir, and Ariely } \\
\text { (2008) }\end{array}$ \\
\hline \multicolumn{4}{|c|}{$\begin{array}{l}\text { Question } 7.1 \text { - Suppose that the tax to be paid will go to education, health, and safety and that you can verify } \\
\text { the application of that tax through benefits to society. Would you run the risk of declaring the lower amount? }\end{array}$} \\
\hline $\begin{array}{l}\text { Internal } \\
\text { reward }\end{array}$ & $\begin{array}{l}\text { Intentionality to carry out fiscal } \\
\text { transparency }\end{array}$ & $\begin{array}{l}\text { Individuals who answered "yes" or "don't know" have } \\
\text { the intention to practice tax evasion, and those who } \\
\text { answered "no" are less likely to have the dishonest } \\
\text { intention. }\end{array}$ & $\begin{array}{l}\text { Pashev (2005), Feld and Frey } \\
\text { (2007) }\end{array}$ \\
\hline \multicolumn{4}{|c|}{$\begin{array}{l}\text { Question } 8 \text { - Suppose that your annual earnings were } R \$ 200,000.00 \text { and that you will have to pay } R \$ 8,000.00 \text { in taxes, but } \\
\text { you can reduce that value to } R \$ 5,000.00 \text {. However, you will have to pay } R \$ 2,000.00 \text { to understand the legislation and } \\
\text { your rights. Would you make the payment? }\end{array}$} \\
\hline $\begin{array}{l}\text { Internal } \\
\text { reward }\end{array}$ & $\begin{array}{l}\text { Intentionality regarding the cost } \\
\text { of tax compliance }\end{array}$ & $\begin{array}{l}\text { Individuals who answered "yes" or "don't know" are } \\
\text { less likely to practice tax evasion, and those who } \\
\text { answered "no" are likely to have the dishonest intention. }\end{array}$ & $\begin{array}{l}\text { Dean et al. (1980), Diniz et al. } \\
\text { (2009) }\end{array}$ \\
\hline \multicolumn{4}{|c|}{ Question 8.1 - Would you run the risk of paying $\mathrm{R} \$ 5,000.00$ without understanding the legislation and your rights? } \\
\hline $\begin{array}{l}\text { Internal } \\
\text { reward }\end{array}$ & $\begin{array}{l}\text { Non-intentionality regarding the } \\
\text { cost of tax compliance }\end{array}$ & $\begin{array}{l}\text { Respondents who adopted the "yes" or "don't know" } \\
\text { options would be more likely to be dishonest, and those } \\
\text { who answered "no" are less likely to have the dishonest } \\
\text { intention regarding error in the elaboration of tax } \\
\text { procedures. }\end{array}$ & $\begin{array}{l}\text { Dean et al. (1980), Diniz et al. } \\
\text { (2009) }\end{array}$ \\
\hline
\end{tabular}

Source: Elaborated by the authors.

The pre-test for the questionnaire carried out in three stages was conducted with the aim of identifying and eliminating potential problems. The validity of the construct was sustained by the theoretical framework of the subject and all the variables were instituted through a consistent relationship with similar variables derived from the theory, as explained in Table 2.

In this study, we chose the logistic regression to estimate the probability of being dishonest, where tax evasion was defined as the dependent variable. This statistical technique is appropriate for the use of a categorical dependent variable (Hair et al., 2009) and as it constitutes the analytical basis for this research, as detailed in the next section. The calculations for the factor analysis, factorial adequacy, and econometric model were carried out with the help of the GLM package in the R software (version 3.2.4).

\subsection{Statistical Analysis}

As the dependent variable is binary and qualitative in nature, involving the simple choice between evasion and non-evasion, and the characteristic that influences the decision is the individual's behavior, the appropriate econometric model for this analysis is the binary logistic regression. The Stepwise variable selection method was used.

The logistic regression model adopted for this research is the logit model, in which the classification of each individual in one group, or another group, is observed in the sample, and the probability of an individual belonging to a group is measured, enabling the interpretation of the results according to the odds ratio (OR) (Gujarati, 2006).

Thus, using the forward procedure, the univariate analysis was conducted, which constituted the adjustment of a model for each one of the variables. The variables that presented a $\mathrm{p}$-value lower than 0.25 were chosen for the multivariate analysis, and then the backward procedure was applied. Therefore, in turn, the highest $\mathrm{p}$-value variables were removed and the procedure was repeated until only significant variables were left in the model. For the backward method, the $5 \%$ significance level measured by the Wald p-value was adopted. 


\section{ANALYSIS OF THE RESULTS}

To measure dishonesty, each respondent's answers regarding the number of right answers in the mathematical test mentioned on the collection voucher were used. Therefore, those participants who were not truthful in the quantity of right answers mentioned on the collection voucher were considered dishonest. With relation to the socioeconomic questionnaire model, this was classified into identified and not identified, where the respondents to the model identified were under the detection condition, while the rest were not under that condition.

The database is formed of 598 individuals participating in the research, who were analyzed using the external rewards and internal rewards constructs. In the descriptive analysis of the categorical variables, absolute and relative frequencies were used, while in the description of the age variable, position, central tendency, and dispersion measures were chosen, as can be observed in Table 3 .

Table 3

Description of the categorical variables

\begin{tabular}{|c|c|c|c|}
\hline & Variables & $\mathbf{n}$ & $\%$ \\
\hline \multirow{2}{*}{ Gender } & Female & 267 & 44.6 \\
\hline & Male & 331 & 55.4 \\
\hline \multirow{2}{*}{ Honest } & No & 148 & 24.7 \\
\hline & Yes & 450 & 75.3 \\
\hline \multirow{2}{*}{ Identified } & No & 328 & 54.8 \\
\hline & Yes & 270 & 45.2 \\
\hline \multirow{7}{*}{ Profession } & Administrator & 132 & 22.1 \\
\hline & Lawyer & 18 & 3.0 \\
\hline & Accountant & 265 & 44.3 \\
\hline & Economist & 21 & 3.5 \\
\hline & Engineer & 58 & 9.7 \\
\hline & Public servant & 27 & 4.5 \\
\hline & Others & 77 & 12.9 \\
\hline \multirow{5}{*}{ Family income } & Less than $\mathrm{R} \$ 4,000.00$ & 170 & 28.4 \\
\hline & $\mathrm{R} \$ 4,000.01$ to $\mathrm{R} \$ 8,000.00$ & 241 & 40.3 \\
\hline & $\mathrm{R} \$ 8,000.01$ to $\mathrm{R} \$ 16,000.00$ & 138 & 23.1 \\
\hline & $\mathrm{R} \$ 16,000.01$ to $\mathrm{R} \$ 32,000.00$ & 43 & 7.2 \\
\hline & $\mathrm{R} \$ 32,000.01$ to $\mathrm{R} \$ 64,000.01$ & 6 & 1.0 \\
\hline \multirow{6}{*}{ Region } & Central-West & 176 & 29.4 \\
\hline & Northeast & 105 & 17.6 \\
\hline & North & 143 & 23.9 \\
\hline & Southeast & 68 & 11.4 \\
\hline & South & 106 & 17.7 \\
\hline & Age* & 32.34 & 9.08 \\
\hline
\end{tabular}

* Mean and standard deviation.

Source: Elaborated by the authors.

To evaluate whether the use of the factor analysis was suitable for the research data, the Kaiser-MeyerOlkin (KMO) sampling adequacy measure was used and both constructs were adequate, since all the KMOs were equal to 0.50 . And, finally, both constructs were one-dimensional according to the parallel lines criteria, inferring that they are associated with each other and represent a single concept, as is observed in the data presented in Table 4.
Note that $68.7 \%$ of the participants present a family income lower than $\mathrm{R} \$ 8,000.00$, indicating that they could have less propensity for tax evasion, given that, under the risk-aversion hypothesis, such evasion can decrease as income decreases, when the individual assumes less risks as their wealth decreases, because risk aversion is decreasing. It also warrants mentioning that $55 \%$ of the respondents are male. 
Table 4

Convergent validity, reliability, and dimensionality of the constructs

\begin{tabular}{|c|c|c|c|c|c|c|}
\hline Construct & Items & AVE & $\mathrm{CA}$ & CR & KMO & DIM \\
\hline External rewards & 2 & 0.73 & 0.63 & 0.76 & 0.50 & 1 \\
\hline Internal rewards & 2 & 0.54 & 0.13 & 0.60 & 0.50 & 1 \\
\hline
\end{tabular}

$C A=$ Cronbach's alpha; $A V E=$ average variance extracted; $C R=$ composite reliability; DIM = Dimensionality; $K M O=K a i s e r-$ Meyer-Olkin (adequacy of the sample).

Source: Elaborated by the authors.

It is verified, in Table 4, that all the constructs presented an average variance extracted (AVE) higher than 0.50; therefore, the latent variable explains the variance of their indicators, where the external rewards construct presented an AVE of 0.73 and the internal rewards AVE was 0.54. The external rewards construct was constituted of the detection probability and penalty variables, while the internal rewards construct was composed of the religiosity, self-concept, social norm, fiscal transparency, and cost of tax compliance variables. It is observed that the low Cronbach's alpha for the internal rewards construct can be explained by the small number of items that formed part of the scale. The analysis conducted with all the items and verifying the effect of removing each item over that statistic showed that religiosity was important for the reduced value of that statistic.

\subsection{Influence of External Rewards}

Table 5 reveals the estimate of the $\beta$ coefficients, the OR, the confidence interval, and the probability of significance of the variables that belong to the study of the external rewards.

Table 5

Influence of external rewards on dishonesty

\begin{tabular}{|c|c|c|c|c|c|c|c|c|c|c|}
\hline \multirow{2}{*}{ Variables } & & \multicolumn{2}{|c|}{ Honest } & \multicolumn{2}{|c|}{ Dishonest } & \multirow{2}{*}{$\beta$} & \multirow{2}{*}{ SE $(\beta)$} & \multirow{2}{*}{ OR } & \multirow{2}{*}{$\mathrm{Cl} 95 \%$} & \multirow{2}{*}{ p-value } \\
\hline & & $\mathbf{n}$ & $\%$ & $\mathbf{n}$ & $\%$ & & & & & \\
\hline \multirow{3}{*}{$\begin{array}{l}\text { Detection } \\
\text { probability } \\
\text { (Q5) }\end{array}$} & Yes & 50 & 71.4 & 20 & 28.6 & - & - & 1.00 & - & - \\
\hline & Don't know & 40 & 70.2 & 17 & 29.8 & 0.06 & 0.39 & 1.06 & $(0.49 ; 2.29)$ & 0.877 \\
\hline & No & 360 & 76.4 & 111 & 23.6 & -0.26 & 0.29 & 0.77 & $(0.44 ; 1.35)$ & 0.363 \\
\hline \multirow{3}{*}{$\begin{array}{l}\text { Penalty } \\
\text { (Q5.1) }\end{array}$} & Yes & 38 & 55.1 & 31 & 44.9 & - & - & 1.00 & - & - \\
\hline & Don't know & 39 & 73.6 & 14 & 26.4 & -0.82 & 0.39 & 0.44 & $(0.20 ; 0.95)$ & 0.037 \\
\hline & No & 373 & 78.4 & 103 & 21.6 & -1.08 & 0.27 & 0.34 & $(0.20 ; 0.57)$ & 0.000 \\
\hline
\end{tabular}

$S E=$ standard error of the coefficient; C195\% $=95 \%$ confidence interval; OR = odds ratio.

Source: Elaborated by the authors.

he detection probability was analyzed using the data from Q5 and did not present statistical significance at a $5 \%$ confidence level. Therefore, the results of this research go against the findings of previous studies (Mazar \& Ariely, 2006). However, this result suggests that the magnitude of the reward may be related to the detection probability exercised through inspection, which can generate penalties (Allingham \& Sandmo, 1972). Thus, individuals evaluate the cost-benefit of illicit practices depending on the punishment, without taking into account the detection probability. For Fung (2015), detection probability is associated with risk aversion, since individuals feel the need to be safe in an uncertain environment. Therefore, the results indicate a sample formed of risk-averse individuals.
In contrast, the penalty presented a significant difference $(\mathrm{p}<0.001)$ between the individuals who answered "no" and "yes," where those who answered "no" presented a $0.34(0.20 ; 0.57)$ times lower chance of being dishonest than those who answered "yes." Among the individuals who answered "no," the proportion of dishonesty was $21.6 \%$, while for those who answered "yes" the proportion was $44.9 \%$. Therefore, the penalty influences dishonesty as a factor that inhibits tax evasion up to a certain point, and these results confirm previous assumptions (Polinsky, 2004). This occurs because individuals may be risk-neutral or risk-averse, so they only commit tax evasion if the gain exceeds the penalty, without considering the detection probability. Weigel, Hessing, and Elffers (1987), Cowell (1992), and Wenzel (2004) already argued that the tax 
burden generated a feeling of personal injustice and that the individuals evaluated the penalties of an illicit act based only on the punishment. Therefore, it is suggested that the magnitude of the penalty is established according to the individual's behavior; thus, the cost generated with the adoption of an illicit practice constitutes the indicator for measuring the penalty, which enables a reduction in the intrinsic motivation.

\subsection{Influence of Internal Rewards}

A logistic regression was carried out to identify whether the variables that form part of the internal rewards construct can explain dishonest behavior. The explanatory variables of this model were religiosity, self-concept, social norm, transparency, and cost of tax compliance and the results are shown in Table 6.

Table 6

Influence of internal rewards on dishonesty

\begin{tabular}{|c|c|c|c|c|c|c|c|c|c|c|}
\hline \multirow{2}{*}{ Variables } & & \multicolumn{2}{|c|}{ Honest } & \multicolumn{2}{|c|}{ Dishonest } & \multirow{2}{*}{$\beta$} & \multirow{2}{*}{ SE $(\beta)$} & \multirow{2}{*}{ OR } & \multirow{2}{*}{$\mathrm{Cl} 95 \%$} & \multirow{2}{*}{ p-value } \\
\hline & & $\mathbf{n}$ & $\%$ & $\mathbf{n}$ & $\%$ & & & & & \\
\hline \multirow{3}{*}{$\begin{array}{l}\text { Religiosity } \\
\text { (Q6) }\end{array}$} & Never & 68 & 81.0 & 16 & 19.0 & - & - & 1.00 & - & - \\
\hline & Sometimes & 178 & 73.9 & 63 & 26.1 & 0.41 & 0.31 & 1.50 & $(0.81 ; 2.78)$ & 0.194 \\
\hline & Often & 204 & 74.7 & 69 & 25.3 & 0.36 & 0.31 & 1.44 & $(0.78 ; 2.64)$ & 0.243 \\
\hline \multirow{3}{*}{$\begin{array}{l}\text { Self-concept } \\
\text { and social } \\
\text { norm }(Q 7)\end{array}$} & Yes & 32 & 53.3 & 28 & 46.7 & - & - & 1.00 & - & - \\
\hline & $\begin{array}{l}\text { Don't } \\
\text { know }\end{array}$ & 35 & 70.0 & 15 & 30.0 & -0.71 & 0.40 & 0.49 & $(0.22 ; 1.08)$ & 0.076 \\
\hline & No & 383 & 78.5 & 105 & 21.5 & -1.16 & 0.28 & 0.31 & $(0.18 ; 0.54)$ & 0.000 \\
\hline \multirow{3}{*}{$\begin{array}{l}\text { Fiscal } \\
\text { transparency } \\
\text { (Q7.1) }\end{array}$} & Yes & 11 & 37.9 & 18 & 62.1 & - & - & 1.00 & - & - \\
\hline & $\begin{array}{l}\text { Don't } \\
\text { know }\end{array}$ & 26 & 66.7 & 13 & 33.3 & -1.19 & 0.51 & 0.31 & $(0.11 ; 0.83)$ & 0.021 \\
\hline & No & 413 & 77.9 & 117 & 22.1 & -1.75 & 0.40 & 0.17 & $(0.08 ; 0.38)$ & 0.000 \\
\hline \multirow{3}{*}{$\begin{array}{l}\text { Cost of tax } \\
\text { compliance } \\
\text { (Q8) }\end{array}$} & Yes & 245 & 79.8 & 62 & 20.2 & - & - & 1.00 & - & - \\
\hline & $\begin{array}{l}\text { Don't } \\
\text { know }\end{array}$ & 48 & 64.0 & 27 & 36.0 & 0.80 & 0.28 & 2.22 & $(1.29 ; 3.84)$ & 0.004 \\
\hline & No & 157 & 72.7 & 59 & 27.3 & 0.40 & 0.21 & 1.49 & $(0.99 ; 2.24)$ & 0.058 \\
\hline \multirow{3}{*}{$\begin{array}{l}\text { Cost of tax } \\
\text { compliance } \\
\text { (Q8.1) }\end{array}$} & Yes & 56 & 74.7 & 19 & 25.3 & - & - & 1.00 & - & - \\
\hline & $\begin{array}{l}\text { Don't } \\
\text { know }\end{array}$ & 57 & 71.3 & 23 & 28.8 & 0.17 & 0.36 & 1.19 & $(0.58 ; 2.42)$ & 0.633 \\
\hline & No & 337 & 76.1 & 106 & 23.9 & -0.08 & 0.29 & 0.93 & $(0.53 ; 1.63)$ & 0.793 \\
\hline
\end{tabular}

$S E=$ standard error of the coefficient; C195\% = 95\% confidence interval; OR = odds ratio.

Source: Elaborated by the authors.

As Table 6 shows, at a 5\% significance level, the selfconcept, social norm, fiscal transparency, and cost of tax compliance variables (Q8) were statistically significant. However, in relation to the cost of tax compliance (Q8.1) the results were not statistically significant, which enables it to be inferred that the social norms may have influenced these findings, because when internalized by the individual, they generate a feeling of obligation to comply with them, so as not to be embarrassed if detected adopting illicit practices.

The religiosity variable was analyzed according to the frequency of church attendance and was separated into the following frequencies: never, sometimes (once a year and only on religious days), and often (more than once a week, once a week, and once a month), and the results of this research are not consistent with the assumption that individuals who go to church more often would have a lower propensity for dishonesty (Lau et al., 2013), considering that, for this study, the religiosity variable did not present statistical significance. In light of this scenario, it is suggested that an individual's level of religiosity should be analyzed according to its intrinsic nature. Lau et al. (2013) argue that intrinsic religiosity is experienced by the individual, while extrinsic religiosity is only used by the individual and does not affect their tax evasion practices.

Self-concept and social norm are intimately related because it is according to their internal standards that individuals update their self-concept. Thus, these variables were measured using the same question. For this, the moral reminder "evasion is a crime" was used. The results show that the variables presented significant differences ( $p$-value $<0.001$ ) between the individuals who 
answered "no" and "yes." The individuals who answered "no" presented a $0.31(0.18 ; 0.54)$ times lower chance of being dishonest, compared with those who answered "yes." Among the individuals who answered "yes," the proportion of dishonest ones was $46.7 \%$, while for those who answered "no" the proportion was $21.5 \%$. This result enables it to be inferred that self-concept and social norm influence dishonesty. These findings reinforce previous studies (Cialdini \& Trost, 1998; Lapinski \& Rimal, 2005).

This relationship of influence over dishonesty occurs because the individual considers social norms to be important for their moral standard, which influences their self-concept, and when internalized are reflected in their beliefs and actions. This taxpayer's behavior is influenced by the social norms and they feel guilty when they understate their earnings and are not detected, as well as feeling guilty when they are detected adopting illicit practices (Togler, 2003, 2006).

Thus, self-concept and social norm are negatively related with dishonest behavior; that is, the more there is internalization of social norms and the more self-concept is maintained, the lower the chance there is of being dishonest.

With relation to fiscal transparency, there was a significant difference $(\mathrm{p}<0.001)$ between the individuals who answered "no" and "yes," with those answering "no" presenting a 0.17 times lower chance of being dishonest than those who answered "yes." Among the individuals who answered "yes," the proportion of dishonest ones was $62.1 \%$, while for those who answered "no," the proportion was $22.1 \%$; for "don't know" it was $33.3 \%$. These results are consistent with previous findings (Ellis \& Fender, 2003; Feld \& Frey, 2007; Pickhardt \& Prinz, 2014; Zuccolotto \& Teixeira, 2014). Such behavior is reflected in dishonesty according to the trust generated in the individual through the actions of the institutions (Kogler et al., 2013). Given these findings, the research sample can also be characterized with regard to the taxpayer's behavior as an "intrinsic taxpayer," whose category is influenced by the level of trust in the institutions (Frey, 2001). Kelman
(1965) refers to them as "identifiers," as they present consistency between their beliefs and behavior.

Regarding the cost of tax compliance (Q8), there was a significant difference $(\mathrm{p}=0.004)$ between the individuals who answered "yes" and "don't know," where those who answered "don't know" presented a 2.22 (1.29; 3.84) times higher chance of being dishonest than those who answered "yes." Moreover, there was a significant marginal difference ( $\mathrm{p}=0.058)$ between the individuals who answered "yes" and "no," where the chance of being dishonest was $1.49(0.99 ; 2.24)$ times higher for those who answered "no," compared with those who answered "yes." Among the individuals who answered "yes," the proportion of dishonest ones was $20.2 \%$, while for those who answered "don't know" the proportion was $36 \%$ and for those who answered "no" it was $27.3 \%$.

Note that the tax costs were analyzed based on the monetary costs, that is, based on the cost to the taxpayer of being tax compliant. Thus, the data indicate the findings of Dean et al. (1980) and Diniz et al. (2009), in which individuals choose not to incur tax costs, aiming to maximize the rewards.

However, the research findings suggest the results that indicated that $51.33 \%$ of the respondents said they would incur costs to understand the legislation and their rights should not be ignored. From the perspective of maintaining one's self-concept, this result indicates that people will respect the internal norms, even when they have to incur financial losses, with the aim of maintaining a positive self-concept. Thus, it cannot be denied that individuals are influenced in their decisions when there is the need to reevaluate their self-concept. These results support the findings for Q7.

However, when the individual was asked if they would resort to tax evasion without understanding the legislation and their rights (Q8.1), the results were not statistically significant. The data indicate that the research sample may have been composed of risk-averse taxpayers; so, the individual chooses not to evade, aiming to minimize possible penalties. 


\section{CONCLUDING REMARKS}

This study aimed to identify the factors that influence people's behavior regarding tax evasion practices in Brazil based on an analysis of the internal and external rewards. The analysis was conducted using statistical tests obtained in the logistic regression.

According to Attribution Theory, human behavior is motivated by internal factors that correspond to the attitudes executed through the individual's free will and control, and external factors that reflect the attitudes stimulated by someone or by a particular situation. Thus, individuals explain the causes and reasons for their behaviors and those of others based on distinctiveness, consensus, and consistency. In relation to external aspects, it is understood that dishonest acts by an individual are influenced by the detection probability and penalty, while internal aspects are inherent to the environment of internalization of social norms; that is, they derive from the attribution of personal causality depending on the individual's control.

It was verified, by means of the approach related to each item of the construct, that the external reward, exercised through the penalty, influenced the chance of dishonesty. Yet, the detection probability was not statistically significant.

Studies have revealed that an increase in the detection probability discourages the propensity for dishonesty. However, as the detection probability depends on inspection, which can imply punishment, the individual assumes a rational expected utility maximizer with risk aversion. In contrast, under the risk aversion hypothesis, tax evasion can increase as income increases, when the individual takes on more risks as their wealth increases, because risk aversion decreases. In light of this context, a benchmark for inhibiting tax evasion practices would be to determine the penalties in relation to the cost-benefit, increasing the penalties the more the benefits exceed the external benefits generated.

Thus, the individuals' behavior did not express the assumption of an association with the detection probability and penalties, as indicated by the EUT model.

To determine whether the internal rewards influence dishonesty, the relationship between religiosity, selfconcept, social norms, fiscal transparency, cost of tax compliance, and dishonesty in tax evasion was analyzed. The statistical tests indicated that self-concept, social norms, fiscal transparency, and cost of tax compliance influenced the individuals' dishonest behavior in terms of tax evasion practices in Brazil; however, religiosity did not present any statistical significance.

The results obtained in this research reinforce the idea that the motivational factors of dishonesty are dependent on individuals' intrinsic stimuli, and are conditioned by economic and behavioral factors. Thus, this set of evidence enables the thesis that tax evasion practices in Brazil are influenced by personal and impersonal factors to be defended.

These results highlight that bodies responsible for curbing the adoption of illicit practices, within the tax context, should consider the diversity of taxpayers' behavior, without ignoring their intrinsic motivations, with an emphasis on demographic, economic, and behavioral variables, as well as on moral and social factors, given that the individual's behavior is a determinant for understanding their attitude with regard to illegal practices.

The implications for academia may be important to help, by refining the assumptions, in studying the factors that influence tax evasion, opening up space for the development of new lines of investigation, given that the results indicated that the taxpayer's behavior is not carried out based only on the assumptions of the economic models.

The limitations of this study are explained so that due care can be taken when using the results. However, the authors understand that the tax authority inspection environment is complex and this research is unable to fully cover all the variables. Thus, Q5 was used to bring the respondent closer to a detection situation. However, it is considered that the study may shed light on important questions that could guide more research and discussions in the area, given the taxpayer's perception regarding the limitation of the inspection structure of the Brazilian Internal Revenue Service, concentrating on efforts to audit more taxpayers, as well tax decadence.

Although the questionnaire was pre-tested and its validity and reliability were evaluated, each respondent's interpretations may be different, as they reflect each one's understanding and judgement regarding what is being asked.

Future studies could aim to investigate a defined target public, as well as validating another data collection instrument. To provide continuity to this study, we recommend investigating other psychological factors and variables, such as positive rewards, with the aim of 
improving the empirical evidence regarding the individual subjective factors that determine an individual's tax behavior.

Specifically regarding the results for religiosity, the authors would like to draw attention to the fact that this variable can have both internal and external elements.
Moreover, as the research used church attendance as a proxy for religiosity, this may have influenced the result. In practical terms, an individual can be religious without attending church or attend church without effectively being religious. This may be a challenge for future studies.

\section{REFERENCES}

Adams, J. S. (1965). Inequity in social exchange. In L. Berkowitz, Advances in experimental social psychology (pp. 267-299). New York, NY: Academic Press.

Allingham, M. G., \& Sandmo, A. (1972). Income tax evasion: A theoretical analysis. Journal of Public Economics, 1(3-4), 323338.

Allport, G. W. (1950). The individual and his religion. New York, NY: MacMillan.

Alm, J. (1995). Economic and noneconomic factors in tax compliance. Kyklos, 48(1), 3-18.

Alm, J. (2012). Measuring, explaining, and controlling tax evasion: Lessons from theory, experiments, and field studies. International Tax and Public Finance, 9(1), 54-77.

Andrighetto, G., Zhang, N., Ottone, S., Ponzano, F., D’Attoma, J., \& Steinmo, S. (2016). Are some countries more honest than others? Evidence from a tax compliance experiment in Sweden and Italy. Frontiers in Psychology, 7, 472.

Artonson, E. (1996). A theory of cognitive dissonance: a currente perspective. In: Berkowitz, L. (Ed.). Advances in experimental social psychology, 4, 1-34.

Baldry, J. C. (1986). Tax evasion is not a gamble: A report on two experiments. Economic Letters, 22(4), 333-335.

Baumeister, R. F. (1998). The self. In D. T. Gilbert, S. T. Fiske, \& G. Lindzey, The handbook of social psychology (pp. 680-740). New York, NY: McGraw-Hill.

Becker, G. D. (1968). Crime and punishment: An economical approach. Journal of Political Economy, 76(2), 169-217.

Bem, D. J. (1972). Self-perception theory. In L. Berkowitz, Advances in experimental social psychology (pp. 1-62). New York, NY: Academic Press.

Birnberg, J. G., Turopolec, L, Young, S. M. (1983). The organizational context of accounting. Accounting, Organizations and Society, 8(2-3), 111-129.

Bloomquist, K. M. (2006). A comparison of agent-based models of income tax evasion. Social Science Computer, 24(4), 411-425.

Butterfield, K. D., Trevino, L. K., \& Ball, G. A. (1996). Organizational punishment from the manager's perspective: A grounded investigation and inductive model. Academy of Management Journal, 39(6), 1479-1512.

Campbell, E. Q. (1964). The internalization of moral norms. Sociometry, 27(4), 391-412.

Castillo, M., Petrie, R., Torero, M., \& Vizeisza, A. (2011). Lost in the mail: A field experiment on crime. Andrew Young School of Policy Studies [Working Paper]. Georgia State University.
Chau, G., \& Leung, P. (2009). A critical review of Fischer tax compliance model: A research synthesis. Journal of Accounting and Taxation, 1(2), 34-40.

Chiarini, B., Marzano, E., \& Schneider, F. (2013). Tax rates and tax evasion: An empirical analysis of the long-run aspects in Italy. European Journal of Law and Economics, 35(2), 273-293.

Cialdini, R. B., \& Trost, M. R. (1998). Social influence: Social norms, conformity and compliance. In D. T. Gilbert, S. T. Fiske, \& G. Lindzey (Eds.), The handbook of social psychology (pp. 151-192). New York, NY: McGraw-Hill.

Cowell, F. A. (1992). Tax evasion and inequity. Journal of Economic Psychology, 13(4), 521-543.

CNS Resolution n. 466/2012. (2012). Establishes guidelines and regulatory standards for research involving human beings. Retrieved from http://conselho.saude.gov.br/resolucoes/2012/ Reso466.pdf.

Dean, P., Keenan, T., \& Kenney, F. (1980). Taxpayers attitudes to income tax evasion: An empirical survey. British Tax Review, $1(1), 28-44$.

Dilulio, J., \& John, J. (1996). Help wanted: Economists, crime and public policy. The Journal of Economic Perspectives, 10(1), 3-24.

Diniz, E. H., Barbosa, A . F., Junqueira, A. R. B., Prado, O. (2009). O governo eletrônico no Brasil: perspectiva histórica a partir de um modelo estruturado de análise. Revista de Administração Pública, 43(1), 23-48.

Durkheim, E. (1949). The division of labor in society. Wilmington, IL: Free Press.

Ellis, C. J., \& Fender, J. (2003). Corruption and transparency in a growth model. International Tax and Public Finance, 13(2-3), 115-149.

Evans, C., Lignier, P., \& Tran-Nam, B. (2013). Tax compliance costs for the small and medium enterprise business sector: Recent evidence from Australia [Discussion Paper]. In TAX Administration Research Centre Seminar (3-13). Exeter, Reino Unido: University of Exeter Business School.

Falcão, A. A. (2002). Fato gerador da obrigação tributária. Rio de Janeiro, RJ: Forense.

Feld, L. P., \& Frey, B. S. (2007). Tax compliance as the result of psychological tax contract: The role of incentives and responsive regulation. Law \& Policy, 29(1), 102-120.

Fischbacher, U., \& Föllmi-Heusi, F. (2013). Lies in disguise: An experimental study on cheating. Journal of the European Economic Association, 11(3), 525-547. 
Fosgaard, T. R. (2013). Asymmetric default biasin dishonesty: How defaults work but only when in one's favor [Working Paper]. University of Copenhagen.

Frey, B. S. (2001). Inspiring economics: Human motivation in political economy. Cheltenham: Edward Elgar.

Friedland, N., Maital, S., \& Rutenberg, A. (1978). A simulation study of income tax evasion. Journal of Public Economics, 10(1), 107-116.

Fung, M. K. (2015). Cumulative prospect theory and managerial incentives for fraudulent financial reporting. Contemporary Accounting Research, 32(1), 55-75.

Glover, R. J. (1997). Relationships in moral reasoning and religion among members of conservative, moderate, and liberal religious groups. The Journal of Social Psychology, 137(2), 247-254.

Gujarati, D. (2006). Econometria básica. Rio de Janeiro, RJ: Campus Elsevier.

Hair, J. F., Jr., Black, W. C., Babin, B. J., Anderson, R. E., Tatham, R. L., \& Gouveia, M. A. (2009). Análise multivariada de dados. Tradução Adonai Schlup Sant'Anna ( $6^{\text {th }}$ ed.). Porto Alegre, RS: Bookman.

Hanlon, M., \& Heitzman, S. (2010). A review of tax research. Journal of Accounting and Economics, 50(2-3), 127-178.

Harris, S. L., Mussen, P. H., \& Rutherfor, E. (1976). Some cognitive, behavioral, and personality correlates of maturity of moral judgment. Journal of Genetic Psychology, 124(1), 123-135.

Heider, F. (1958). The psychology of interpersonal relations. New York, NY: Wiley.

Henrich, J., Boyd, R., Bowles, S., Camerer, C., Fehr, E., Gintis, H., et al. (2001). In search of homo economicus: Behavioral experiments in 15 small-scale societies. American Economic Review, 91(2), 73-78.

Karni, E., \& Safra, Z. (1987). Preference reserve and the observability of preferences by experimental methods. Econometrica, 55(3), 675-685.

Kelman, H. (1965). Manipulation of human behavior: An ethical dilemma for the social scientist. Journal of Social, 21(2), 31-46.

Kogler, C., Batrancea, L., Nichita, A., Pantya, J., Belianin, A., Kirchler, E. (2013). Trust and power as determinants of tax compliance: Testing the assumptions of the slippery slope framework in Austria, Hungary, Romania and Russia. Journal of Economic Psychology, 34, 169-180.

Kopits, G., \& Craing, J. (1998). Transparency in government operations. Retrieved from https://www.imf.org/external/ pubs/ft/op/158/op158.pdf.

Lapinski, M. K., \& Rimal, R. N. (2005). An explication of social norms. Communication Theory, 15(2), 127-147.

Lau, T. C., Choe, K. L., \& Tan, L. P. (2013). The moderating effect of religiosity in the relationship between money ethics and tax evasion. Asian Social Science, 9(11), 213-220.

Loomes, G., Starmer, C., \& Sugden, R. (1991). Observing violations of transitivity by experimental methods. Econometrica, 59(2), 425-439.
Mazar, N., \& Ariely, D. (2006). Dishonesty in everyday life and its policy implications. Journal of Public Policy \& Marketing, 25(1),117-126.

Mazar, N., Amir, O., \& Ariely, D. (2008). The dishonesty of honest people: A theory of self-concept maintenance. Journal of Marketing Research, 45(6), 633-644.

McDaniel, S. W., \& Burnett, J. J. (1990). Consumer religiosity and retail store evaluative criteria. Journal of the Academy of Marketing Science, 18(2), 101-112.

Mittone, L. (2006). Dynamic behavior in tax evasion: an experimental approach. The Journal of Socio-Economics, 35(5), 813-835.

Mota, R. G. (2012). Aspectos relevantes da concorrência fiscal internacional. Revista da Procuradoria-Geral da Fazenda Nacional, 2(2), 45-70.

Nagin, D. S., \& Pogarsky, G. (2003). An experimental investigation of deterrence: cheating, selfserving bias, and impulsivity. Criminology, 41(1), 167-194.

Pashev, K. V. (2005). Tax compliance of small business in transition economies: Lessons from Bulgaria. Retrieved from https://ssrn. com/abstract $=717041$.

Pernías, T. R. (2017). Sonegação fiscal, o esporte predileto das elites. Retrieved from https://www.cartacapital.com.br/blogs/brasildebate/sonegacao-fiscal-o-esporte-predileto-das-elites/.

Pickhardt, M., \& Prinz, A. (2014). Behavioral dynamics of tax evasion. Journal of Economic Psychology, 4(C), 1-19.

Ploner, M., \& Regner, T. (2013). Self-image and moral balancing: An experimental analysis. Journal of Economic Behavior and Organization, 93(C), 374-383.

Polinsky, A. M. (2004). The optimal fines and auditing when wealth is costly to observe. International Review of Law and Economics, 26(3): 323-335.

Polinsky, A. M., \& Shavell, S. (1979). The optimal tradeoff between the probability and magnitude of fines. American Economic Review, 69(5), 880-891.

Rachlin, H. (1970). Introdution to modern behaviourism. New York, NY: Freeman.

Rokeach, M. (1973). The nature of human values. New York, NY: Free Press.

Sá, C., Martins, A., \& Gomes, C. F. (2014). Tax morale, occupation and income level: An analysis of portuguese taxpayers. Journal of Economics, Business and Management, 2(2), 112-116.

Sandford, C. A., Godwin, M., Hardwick, P. (1989). Administrative and compliance costs of taxation. In Association Fiscale Internationale. Cahiers de Droit Fiscal International. 10111012. Roterdam: Kluwer Law.

Schneider, D. G., \& Parente, M. A. M. P. (2006). O desempenho de adultos jovens e idosos na Iowa Gambling Task (IGT): um estudo sobre a tomada de decisão. Psicologia: Reflexão e Crítica, 19(3), 442-450.

Schwartz, R. D., \& Orleans, S. (1967). On legal sanctions. Law Review, 34(2), 247-300.

Shalvi, S., \& Leiser, D. (2013). Moral firmness. Journal of Economic Behavior and Organization, 93(C), 400-407. 
Shaw, J., Slemrod, J., \& Whitting, J. (2008). Administration and compliance [working paper]. In Report of a Commission on Reforming the Tax System for the 21st Century. Oxford: The Institute for Fiscal Studies.

Siqueira, M. L., \& Ramos, F. S. (2006). A economia da sonegação: teorias e evidências empíricas. Economia Aplicada, 10(3): 399-424.

Spicer, M. W., \& Lee Becker, A. (1980). Fiscal inequity and tax evasion: An experimental approach. National Tax Journal, 33(2), 171-175.

Thaler, R. H. (1990). Anomalies: Saving, fungibility, and mental accounts. The Journal of Economic Perspectives, 4(1), 193-205.

Thaler, R. H. (1999). Mental accounting matters. Journal of Behavioral Decision Making, 12(3), 183-206.

Thaler, R., \& Shefrin, H. (1981). An economic theory of selfcontrol. Journal of Political Economy, 89(2), 392-406.

Thibaut, J., Friedland, N., \& Walker, L. (1974). Compliance with rules: Some social determinants. Journal of Personality and Social Psychology, 30(6), 792-801.

Torgler, B. (2003). To evade taxes or not to evade; that is the question. Journal of Behavioral and Experimental Economics, 32(3), 283-302.

Torgler, B. (2005). Tax morale in Latin America. Journal of Public Finance and Public Choice, 122(1-2), 133-157.

Torgler, B. (2006). The importance of faith: tax morale and religiosity. Journal of Economic Behaviour \& Organization, 61(1), 81-109.

Torgler, B. (2007). Tax compliance and tax morale: a theoretical and empirical analysis. Cheltenham, UK: Edward Elgar.
Torgler, B., \& Schneider, F. (2007). Shadow economy, tax morale, governance and institutional quality: a panel analysis. Discussion Paper, 2563.

Trevino, L. K. (1992). The social effects of punishment in organizations: A justice perspective. The Academy Management Review, 17(4), 647-676.

Tversky, A., \& Kahneman, D. (1992). Advances in prospect theory: Cumulative representations of uncertainty. Journal of Risk and Uncertainty, 1992(5), 297-323.

Von Neumann, J., \& Morgenstern, O. (1953). Theory of games and economic behavior. Princeton, NJ: Princeton University.

Weigel, R. H., Hessing, D. J., \& Elffers, H. (1987). Tax evasion research: A critical appraisal and theoretical model. Journal of Economic Psychology, 8(2), 215-235.

Weiner, B. (1976). An attributional approach for educational psychology. Review of Research in Education, 4(1), 179209.

Wenzel, M. (2004). The social side of sanctions: Personal and social norms as moderators of deterrence. Law \& Human Behavior, 28(5), 547-567.

World Values Survey. (2015). Crossings by country. Retrieved from http://worldvaluessurvey.org.

Zaklan, G., Westerhoff, F., \& Stauffer, D. (2009). Analysing tax evasion dynamics via the Ising model. Journal of Economic Interaction and Coordination, 4(1), 1-14.

Zuccolotto, R., \& Teixeira, M. A. (2014). The causes of fiscal transparency: Evidence in the Brazilian states. Revista Contabilidade \& Finanças, 25(66), 242-254. 